\section{Myter og mandsmod}

\author{
Redningen af de danske jøder i oktober \\ 1943 har spillet en stor rolle for \\ danskernes ry og selvforståelse. I en ny \\ bog gennemgår historikeren Sofie Bak \\ myter, modmyter og kendsgerninger \\ knyttet til begivenheden og trækker et \\ perspektiv frem til den skarpe tone i \\ dagens aktuelle fremmeddebat.
}

\section{Afph.d.-studerende Sofie Bak}

F or nylig den blev jeg ringet op af en svensk tv-journalist som gerne ville tale om danskerne og den aktuelle indvandrerdebat. Svenskerne har meget svært ved at forstå hvad det er der er sket med danskerne, hvorfor de har ændret syn på flygtninge og indvandrere, og hvad der er blevet af den hyggelige og fornuftige dansker, fortalte journalisten. Sådanne spørgsmål vil der kunne gives mange svar på, og mine egne personlige hører slet ikke til de særligt kvalificerede eller neutrale. Men at svenskernes overraskelse over danskerne måske har noget at gøre med redningen af de danske jøder for næsten 60 år siden, er ikke fuldkomment usandsynligt. Danmark har siden begivenheden blev kendt i den frie verden haft et ganske særligt renommé, når talen falder på Holocaust, som nøje knyttes til forsvaret for menneskerettigheder og demokrati. Den storstilede redningsaktion i oktober 1943 er et helt exceptionelt fænomen. Dels fordi den danske befolkning reagerede massivt og kollektivt, dels fordi redningsaktionen var en succes. I mange år har redningen stået som en ganske ubegribelig begivenhed, for hvordan kunne en sådan redningsaktion lade sig gøre under et nazistisk regimente - alle de gode danske viljer ufortalte?

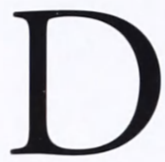
e sidste næsten 60 års forskning har peget på flere muligheder, og overset og fortrængt andre. I dag besidder historikerne ny viden om aspekter af redningsaktionen, som tidligere enten har været taget for givet, eller som blot er blegnet i erindringen. Redningsaktionen er ikke længere så ubegribelig endda: Den nyere forskning har bragt os tættere på en forståelse af de tyske forudsætningerne for, at danskernes spontane indsats til fordel for en minoritet, som var udset til udskillelse og forfølgelse, kunne føre til et så spektakulært resultat. Dermed gives vi indsigt i de mekanismer og egenskaber ved det nazistiske bureaukrati, som i Danmark gav mulighed for en individuel fortolkning og kreativitet, der saboterede den ellers gnidningsløse nazistiske udryddelsesproces. Ligeledes var der særtræk ved den danske besættelsessituation og det danske samfund, som kan fortælle os noget om, hvad der gjorde os anderledes, hvor vi handlede rigtigt og om de vilkår, som afgjorde, at en stor del af danskerne trådte ud af passiviteten for at hjælpe de forfulgte. For så vidt er dette billede af begivenhederne i 1943 ikke mindre fabelagtigt end myterne.

\section{Jødespørgsmålet}

T besættelsens første år blev det såkaldte ,jødespørgsmål“ jævnligt berørt af magthaverne i Berlin, men et sådant blev kategorisk afvist som ikke-eksisterende af den danske regering. De danske myndigheder modstod presset for diskriminerende love over for jøderne i et samspil med besættelsesmagtens officielle repræsentant $\mathrm{i}$ Danmark Cecil von Renthe-Fink, og hans efterfølger Werner Best, som sikrede at 

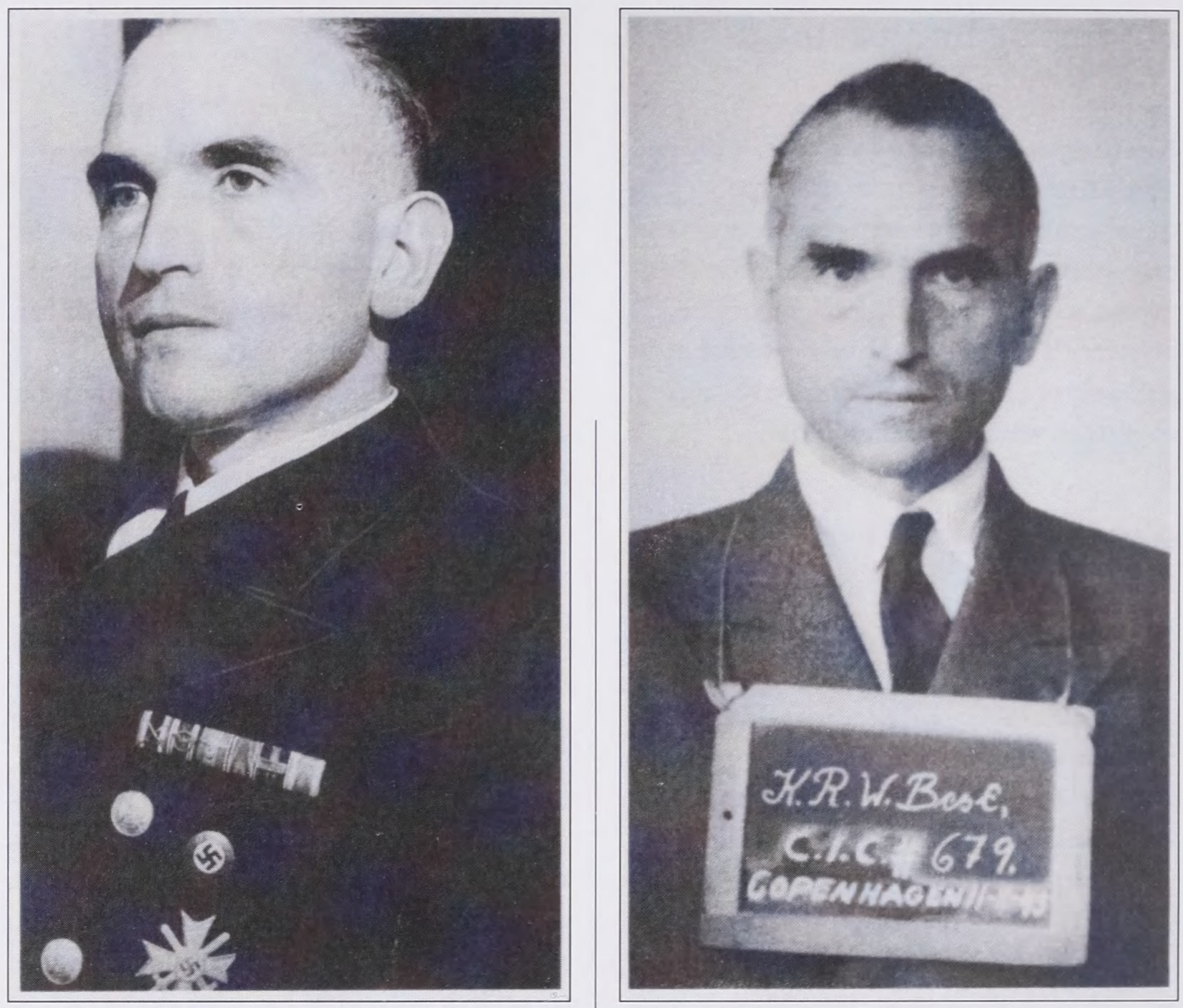

To udgaver af Best. Karrierediplomaten, SS-Gruppenfïhrer, dr.jur. Werner Best i sin bedste alder, nesten til fuldkommenhed realiseringen af det ariske ideal - og forbryderbilledet af en slagen mand i 1945, tilsyneladende pa vanviddets rand. (Foto: Frihedsmuseet).

Danmark i flere tilfælde blev holdt uden for afgørelse i jødespørgsmålet og afværgede tiltag for registrering og identifikation af de danske jøder. Begge anså de antisemitiske aktioner for skadelige for de tyske interesser $\mathrm{i}$ Danmark og gjorde det argument gældende overfor Berlin, at de gode relationer til den danske regering ikke burde sættes på spil for nogle få tusinde jøders skyld. Man udsatte derfor den såkaldte Endlösung der Judenfrage, "den endelige løsning af jødespørgsmålet" i Danmark.
I sommeren 1943 var situationen $i$ landet imidlertid en anden som følge af en bølge af strejker og sabotagehandlinger. Best blev kaldt til Berlin d. 24. august og fik $\mathrm{i}$ en dundertale rigsregeringens harme $\mathrm{a}^{+}$føle. Tilbage i København stillede han den danske regering overfor et drastisk ultimatum; bl.a. krav om undtagelsestilstand, pressecensur og dødsstraf for sabotage og våbenbesiddelse. Den 29. august 1943 brød samarbejdspolitikken sammen, regeringen trådte tilbage og der blev 
proklameret militær undtagelsestilstand.

B est befandt sig nu i en udsat position både i forhold til Fører hovedkvarteret, som betvivlede hans evner og myndighed, og i forhold til chefen for værnemagten general von Hanneken, som situationen gav ekstraordinære beføjelser. For at befæste sin situation anlagde han derfor en dobbeltstrategi: Mens han opfordrede til jødeaktion i Danmark i ly af den militære undtagelsestilstand, forberedte han forudsætningerne for aktionens fiasko.

Stort set alle tyske instanser, både det tyske politi og værnemagten i Danmark, udtrykte misfornøjelse ved udsigten til en aktion mod de danske jøder. Det gjaldt bl.a. chefen for det tyske sikkerhedspoliti, Rudolf Mildner, som var ankommet til Danmark fra en post som Gestapochef i Kattowitz i Polen, hvor han havde været formand for det politiske udvalg i Auschwitz-lejren og medlem af SS-domstolen. Mildner søgte bl.a. at forhindre aktionen gennem samtaler med Gestapo i Berlin. Alle frygtede de, at aktionen ville skabe opstand $i$ den danske befolkning og ødelægge renommé og samarbejdsmuligheder med de danske myndigheder. I en strøm af telegrammer og ved flere tyske notabiliteters rejse til Berlin forsøgtes aktionen forhindret. For sent og forgæves. 17. september forelå førerordren om gennemførelsen af "den endelige løsning af jødespørgsmålet" i Danmark. Razziaen blev gennemført 15 dage senere.

\section{Redningsaktionens forudsætninger}

I mellemtiden havde Best lækket oplysningerne om aktionen til sin fortrolige ved den tyske gesandtskab, Georg Ferdinand Duckwitz. En mand med excellente forbindelser til det danske socialdemokrati. Duckwitz kastede sig herefter ud en række foretagender. Han rejste både til Berlin for at prøve at afværge aktionen, men kom for sent til at bremse telegrammet, og til Sverige, hvor han drøftede mulighederne for at afværge aktionen med den svenske statsminister Albin Hansson, eller alternativt: om jøderne kunne modtages i Sverige. Sverige protesterede efterfølgende mod aktionen overfor Berlin og tilbød at modtage de flygtende. Dette tilbud kunne den svenske gesandt overbringe Mosaisk Trossamfunds formand C. B. Henriques d. 29. september, og budskabet blev officielt udbredt i svensk radio d. 2. oktober.

Dermed var to ikke uvæsentlige forudsætninger for et lykkeligt scenarium for Best faldet på plads. Sverige ville og forberedte sig på at modtage de flygtende, og jødiske kredse havde fået øjnene op for denne mulighed. Alternativet havde været at gå under jorden, på uvis tid, med alle de vanskeligheder illegaliteten førte med sig. Det har formentlig i princippet været fuldkomment underordnet for Best, om jøderne forlod landet over Øresund til Sverige, eller via deportationstog østpå. Formålet var at gøre det danske territorium judenrein; renset for jøder. Imidlertid var Best klar over, at den fortsatte ro og stabile leverancer af fødevarer til Tyskland afhang af samarbejdet med departementscheferne, som havde overtaget ledelsen af landet efter 29. august 1943. En brutal menneskejagt på de danske jøder, efterfulgt af deportation, anså Best for at være en katastrofe for disse relationer $\mathrm{og}$ for mulighederne for at redde stumperne af samarbejdspolitikken efter Augustoprøret. Han måtte derfor sørge for at så få jøder som overhovedet muligt blev arresteret på razzianatten og undgå deres senere pågribelse. Den storstilede masseredningsaktion som blev det lykkelige 


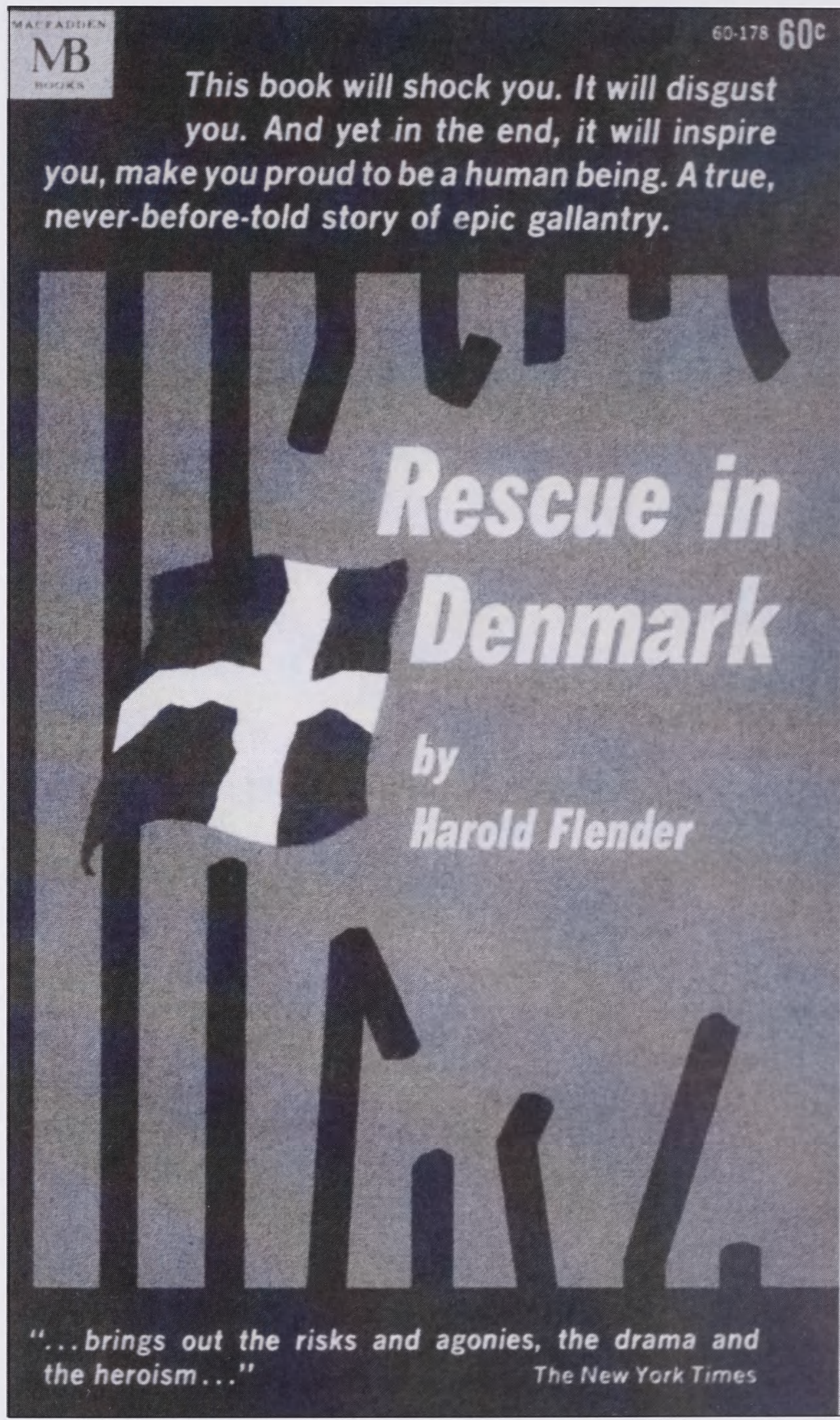

Forsideillustration til den amerikanske bog, Rescue in Denmark, fra 1963, forbloffende nok oversat til dansk i 1993. Harold Flender hager ikke ligefrem om den kontekstuelle og personalhistoriske korrekthed, men bogen er et idealeksempel pa den amerikanske perception af situationen i Danmark og den sentimentale opfattelse aflyset i Holocaust-morket: Det vajende Dannebrog bryder fangselets tremmer. Den ledsagende tekst kunne salge enhver kriminalroman. (Foto: Privateje). 
udkomme i oktober 1943, kunne Best dog næppe have gjort sig håb om, dertil havde man for lidt erfaring med flugtruter over Øresund, og den jødiske ledelse regnede for eksempel ikke med, at danskerne ville hjælpe jøderne på flugt. Men en særdeles vigtig del af strategien blev dog forsøget på at sikre, at jøderne ville blive modtaget i Sverige. Best forsøgte sig endog med legale midler, bl.a. udrejsetilladelser og midlertidige svenske pas. Disse forsøg mødte dog forhindringer og fik ikke nogen reel betydning. Men Best søgte i virkeligheden at genoplive den tvungne udvandring som havde været strategien til løsningen af "jødeproblemet", indtil Reichsfiuhrer-SS Heinrich Himmler i oktober 1942 udstedte forbud mod udvandring fra Tyskland og de besatte områder. Den svenske forbindelse var blandt de opgaver Duckwitz formidlede for Best, foruden at Duckwitz til sidst overbragte advarslen til jødiske kredse.

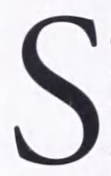

om sidste led i strategien, slappede Best kontrollen i Øresundsregionen. I dag ved vi, at den tyske efterstræbelse af jøderne efter den veltilrettelagte razzia natten mellem d. 1. og 2. oktober var meget begrænset: Der blev ikke gennemført politimæssig overvågning af Øresund $\mathrm{i}$ oktober måned, og de tyske patruljebåde som var til stede på Øresund varetog kun sømilitære opgaver. Mandskabet på de disponible overvågningskuttere var sat af til andet formål i oktober måned. Ikke én eneste transport med jødiske flygtninge blev opbragt af tyske politi. Ligeledes blev den bestående politistyrke ikke sat ind overfor jødernes flugt, og værnemagten forholdt sig trods ordre om at bistå politiet, overvejende passivt. Dertil kommer, at tyskerne var klar over at de næppe kunne regne med det danske kystpolitis loyalitet, men ønskede ikke efterfølgende ordningen med dansk kystkontrol ændret - heller ikke efter at kystpolitibetjentene havde mere end lukket øjnene for jødernes flugt i oktober. En stor del af anholdelserne - omkring halvdelen af det samlede antal anholdelser efter razzianatten (ialt 197) - skete ved én særligt nidkær Gestapo-chef, Hans Juhl i Helsingør. Ved en særlig berygtet razzia i Gilleleje d. 6. oktober blev således hen ved 100 jøder arresteret, 50 blev efterfølgende deporteret. Men derudover var forfølgelsen mere overfladisk og noget præget af tilfældigheder.

I alt blev 481 personer arresteret og deporteret til kz-lejren Theresienstadt. Danskerne blev i modsætning til alle andre fanger i lejren undtaget videre deportation østpå, hvilket skete efter nøje aftale mellem Best og Adolf Eichmann, den praktiske organisator af Endlösungs deportationsprogram. Endvidere enedes de to ved et møde 2 . november om at indskrænke målgruppen for forfølgelsen, således at mennesker over 60 år, halvjøder og jøder gift med ikke-jøder og deres børn blev fritaget fra aktionen, og de diskuterede muligheden for returnering af fejldeporterede. Få uger efter deportationerne fik de danske fanger lov at modtage tøjpakker, breve og medicin og efter nogle måneder, i februar 1944, fik de danske deporterede i Theresienstadt som noget helt enestående lov at modtage fødevarer hjemmefra.

\section{Ud af passiviteten}

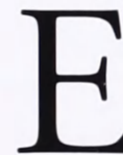

t stort antal mennesker lod sig involvere i redningen af de danske jøder. Hjælpen til jøderne blev formentlig opfattet som en art civil ulydighed i glidende overgang til protest. Både de 


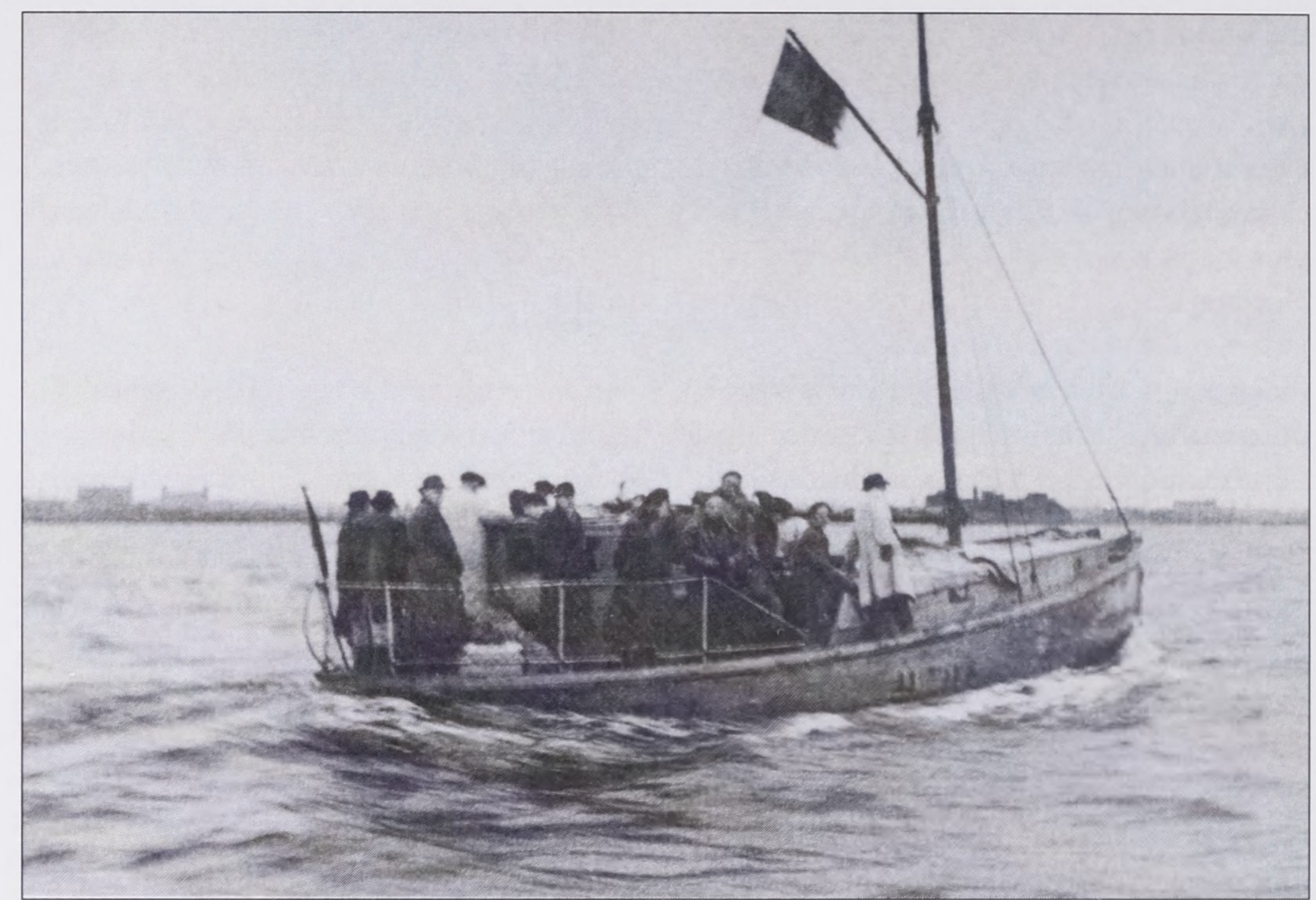

Dette billede optreder i flere fremstillinger om oktober 1943 som en angiveligt sigende

dokumentation for jodernes flugt til Sverige. Imidlertid viser billedet verdenspressens sejlads fra

Malmo til Kobenhavn ved kapitulationen i maj 1945. Mangel på dramatisk billedmateriale fra flugtdagene i oktober og manglende omhu giver anledning til mangfoldige misforstäelser, både $i$ den danske og udenlandske litteratur. (Foto: Frihedsmuseet).

verbale protester, som indløb i dagene omkring razziaen fra organisationer, partier, kirke og kongehus og den mere konkrete hjælp til jøderne var af en sådan kollektiv karakter, at om end princippet individuel straf ikke bortfaldt, reduceredes risikoen dog til et minimum. Eksempelvis opnåede Københavns biskop H. FuglsangDamgaards protestskrivelse, trods det individuelle initiativ, fuld kollektiv styrke ved oplæsningen i kirker landet over den efterfølgende søndag d. 3. oktober 1943. En fornemmelse af hjælpeaktionens større perspektiv og en kollektiv national selvforståelse, hvor danskerne opfattede sig selv som en del af en demokratisk og humanitær nation har afhjulpet den enkeltes isolation og frygt. På denne måde supplerede de protesterende og aktivisterne hinanden. De retfærdiggjorde hinanden. Redningsaktionen red dermed på en bølge af kollektivitet og legitimitet. Selv om en egentlig organisering af flugtruter øjensynligt først kom i gang en uge ind i oktober måned, og de første flugtdage for hjælperne i højere grad har været præget af frygt og mistillid, har enhver genkendelse af ligesindede og enhver forøgelse af hjælpegruppernes antal og midler reduceret angsten og ansvaret. Lokalt samarbejde med det danske kystpoliti bidrog til denne tryghed. Hjælperne organiserede sig forbløffende hurtigt i mindre grupper, som efterfølgende opnåede kontakt med beslægtede netværk og mere 
etablerede modstandskredse. Organiseringen i netværk var et praktisk resultat af flugtsituationen, og redningsindsatsen krævede en kæde af aktioner, fra opsøgning, forvaring og husning til opsamling, afskibning og endeligt selve sejladsen.

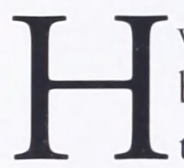
vert enkelt led har haft stor betydning for aktionens effektivitet, selv om de ikke alle indebar samme risiko. Det gjorde beslutningen om at yde hjælp mindre ansvarstung og har givet deltagelsesmuligheder for mange forskellige mennesker - også væsentlig flere end det samlede antal transporter på mellem 600700 umiddelbart antyder. Et stort antal danskere som ikke tidligere havde været involveret $\mathrm{i}$ illegalt arbejde, lod sig nu engagere til fordel for jøderne. Indsatsen var ofte dagligdags og udramatisk, eftersom udlevering af nøgler til et sommerhus, en telefonisk advarsel eller uopfordret økonomisk støtte hører med i kæden. Med redningsaktionen tog en gruppe danskere for første gang konkrete skridt, som de nok måtte frygte at besættelsesmagten ville straffe, men som de samtidig kunne føle sig nogenlunde forvissede om, at de danske myndigheder ville billige. Hermed udviskedes grænserne mellem illegalitet og legalitet og det har for nogle måske givet anledning til en følelse af urørlighed.

\section{Den offentlige opinion}

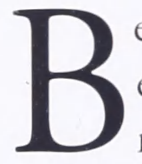

est skabte ikke alene nogle helt enestående forudsætninger for redningsaktionens succes, men indledte tilmed forhandlinger med regimets topfolk til fordel for de danske jøder som var blevet deporteret. Hvad fik mænd som Mildner, Eichmann og Best, som ikke tidligere i deres karriere havde vist blødsødenhed, til at protestere, modificere og sabotere regimets jødepolitik?

$\mathrm{F}$ $\emptyset r s t ~ o g$ fremmest iværksatte Best en kreativ løsning af førerens hensigt: at gøre det nazistiske territorium judenrein. Den officielle deportationspolitik kunne omgås under særlige vilkår. Det danske eksempel taler dermed imod opfattelsen af det tyske system som en monolit, som bevidstløst og systematisk parerer ordre. Danmarks funktion som Monsterprotektorat, idealbilledet på besatte områder under en fremtidig nazistisk verdensorden, krævede særlige hensyn, ikke mindst i forhold til de danske myndigheder. Relationerne måtte ikke belastes yderligere efter 29. august. Det ændrer ikke ved, at de danske politikere systematisk modsatte sig indgreb over for de danske jøder, og benægtede at Danmark havde "et jødeproblem". Best og regimets mænd i Danmark kendte udmærket grænsen for de danske myndigheders tålmodighed og tilpasning. Tilmed forventede de at den danske befolkning ville reagere vredt på en jødeaktion. Bests strategi havde netop danskernes hjælp og solidaritet som forudsætning! Det nyttede - i al fald i Danmarks særlige situation, og med Best ved roret - at sætte sig til modværge. Begivenheden illustrerer dermed den offentlige danske opinions rækkevidde og indflydelse - langt ind i det nazistiske regimes rækker - og viser, at et lille forsvarsløst demokrati faktisk kunne modstå et terrorregime ved at insistere på de gensidige interesser i ro og orden - og på dette punkt, på kompromisløs humanisme.

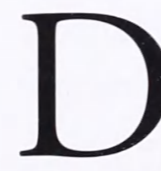
et store netværk af mennesker som lod sig involverede til fordel for jøderne, beretter om demokratisk tankegang og en ringe udbredelse af racistisk antisemitisme og fremmedgørelse over for 
jøderne. Begivenhederne i oktober 1943 er dermed også et bidrag til forståelsen af den gensidige påvirkning mellem politik, holdning og handling og konsekvenserne af en offentlig opinion, som stemplede fremmedhad som usmageligt og udansk.

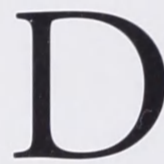
en folkelige opinion og organisationernes, kirkens og myndighedernes protester var så afgørende for redningen af de danske jøder, fordi aktører på tværs af det politiske spektrum, på tværs af skellet mellem modstand og passivitet, og endog på tværs af kløften mellem pro-tysk og anti-nazistisk, var påvirket heraf; både det nazistiske regimes folk i Danmark, og de danskere som vovede civil ulydighed gennem en kollektiv aktion. Denne danske stillingtagen til fordel for jøderne, en kollektiv selvforståelse som opfattede jødeaktionen som en utilgivelig provokation mod nationens værdier, var ikke en selvfølgelighed, ikke et automatisk udslag af en naturgiven national ånd. Holdningen var et praktisk resultat af en møjsommelig og ømfindtlig politisk proces i 1930 'erne, hvor det politiske establishment insisterede på demokratiet og søgte intern mobilisering omkring danske, demokratiske værdier, som skulle danne værn mod den totalitære trussel fra syd og øst, man ikke udadtil kunne forsvare sig imod. Dette forsvar for det parlamentariske system fordele og rummelighed, betød konsekvent afstandtagen og angreb på ikke-demokratiske kræfter, hvad enten de indfandt sig fra højre eller venstre.

S trategien fik forskellige taktiske og praktiske udtryk. Et væsentligt taktisk element blev således latterliggørelsen af den danske nazisme, mens den tyske storebror - i al fald gradvist - blev omfattet med en anden alvor - og selvcensur. En anden dimension blev den offensive indsats overfor antisemitismen. I den politiske debat ved associering mellem antisemitisme og nazisme, ved afvisning af fænomenet som udansk og ved skarp påtale af antisemitiske ytringer.

\section{"Jeg kender ikke meget til jøder, men det strider sgu' imod min religion og min moral, at man jager mennesker, som om de var rotter" \\ (Citat: Københavnsk taxachauffør i oktober 1943 i følge Danmark under den anden verdenskrig, 2, 1965-68, s. 240)}

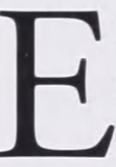
$\mathrm{n}$ offentlig opinion til forsvar for menneskerettigheder og mod racisme kommer ikke af sig selv. Ligesom den politiske kultur og det sprog vi anvender i indvandrer- og flygtningedebatten skal vedligeholdes og fastholdes på et respektfuldt niveau, hvor vi i det mindste prøver at tale om og til hinanden som mennesker, ikke ved kategorier, generaliseringer og fordomme. At man nøje overvåger skredet fra forsøget på at forstå og løse reelle problemer, til angsten for et altoverskyggende social og kulturel trussel - til en uforsonlig benægtelse af muligheden for fredelig sameksistens, for forskellighed overhovedet. Det kræver at der sættes rammer for hvad man kan tillade sig at sige - og at gøre. At man sætter grænser for det anstødelige og uacceptable. Det er disse rammer, der har udvidet sig siden mellemkrigstiden. Til svenskernes forbavselse. 
Noter:

Sofie Bak er født 1973. Cand. Mag. i Historie og Statskundskab. Bogen Jodeaktionen oktober 1943. Forestillinger i offentlighed og forskning, Museum Tusculanums Forlag, (en revideret udgave af Sofie Baks specialeafhandling) udkom i november 2001, og behandler såvel danske som internationale opfattelser af den berømte begivenhed, fra det første værk om redningsaktionen udkom i 1944, over Holocausts begrebets gennembrud i 1960'erne, til 1990'ernes revisionistiske tilgang. Bogen fremhæver den voksende konflikt mellem historikernes synspunkt og de myter som fortsat trives i den offentlige debat, og peger bl.a. på hjælpernes motiver og redningsaktionens kollektive karakter som emner, der kan medvirke til at danne bro mellem forskning og offentlighed. Sofie Baks igangværende ph.d.-projekt om antisemitismen i mellemkrigstiden, fokuserer særligt på fortrængningen af antisemitismen gennem latterliggørelse og tabuisering og redefineringen af den nationale selvforståelse "danskheden", som et led i kampen mod antidemokratiske kræfter.

Denne artikel har tidligere været bragt i $U d s y n$. Tidsskrift for jodisk liv, Israel og Mellemosten, nr. 1, 17. årg., marts 2002. 